\title{
Review Article \\ Naturally Occurring Nrf2 Activators: Potential in Treatment of Liver Injury
}

\author{
Ravirajsinh N. Jadeja, ${ }^{1}$ Kapil K. Upadhyay, ${ }^{2}$ Ranjitsinh V. Devkar, ${ }^{2}$ and Sandeep Khurana ${ }^{1}$ \\ ${ }^{1}$ Digestive Health Center, Medical College of Georgia, Augusta, GA 30912, USA \\ ${ }^{2}$ Division of Phytotherapeutics and Metabolic Endocrinology, Department of Zoology, Faculty of Science, \\ The Maharaja Sayajirao University of Baroda, Vadodara, Gujarat 390002, India
}

Correspondence should be addressed to Sandeep Khurana; skhurana@augusta.edu

Received 17 June 2016; Revised 8 November 2016; Accepted 28 November 2016

Academic Editor: Javier Egea

Copyright (C) 2016 Ravirajsinh N. Jadeja et al. This is an open access article distributed under the Creative Commons Attribution License, which permits unrestricted use, distribution, and reproduction in any medium, provided the original work is properly cited.

Oxidative stress plays a major role in acute and chronic liver injury. In hepatocytes, oxidative stress frequently triggers antioxidant response by activating nuclear erythroid 2-related factor 2 (Nrf2), a transcription factor, which upregulates various cytoprotective genes. Thus, Nrf2 is considered a potential therapeutic target to halt liver injury. Several studies indicate that activation of Nrf2 signaling pathway ameliorates liver injury. The hepatoprotective potential of naturally occurring compounds has been investigated in various models of liver injuries. In this review, we comprehensively appraise various phytochemicals that have been assessed for their potential to halt acute and chronic liver injury by enhancing the activation of Nrf2 and have the potential for use in humans.

\section{Introduction}

Liver has an extraordinary capacity to detoxify compounds that have potential to induce liver injury. As a consequence, the liver is also vulnerable to injury. Although liver injury is a major cause of morbidity and mortality, medical therapies to prevent hepatocyte loss or protect hepatocytes are limited. One example is $\mathrm{N}$-acetylcysteine (NAC), which is used for the treatment of acetaminophen- (APAP-) induced liver injury to promote recovery and reduce the need for liver transplantation. Hence, it is imperative to identify better medical therapies that are hepatoprotective and have minimal side effects.

Naturally occurring compounds have long been used as potential hepatoprotective agents. Drafts such as Ayurveda and traditional Japanese, Chinese, and Kampo (traditional Chinese medicine but adapted to the Japanese culture) medicine recommended the use of formulations of specific plants and fruits in the treatment of liver diseases [1-4]. In recent years, technological advances led to the isolation of active phytochemicals, which are now available as potential therapeutic agents $[5,6]$.
Oxidative stress is a major factor in the mechanism underlying liver diseases. It contributes to the initiation as well as progression of liver injury [7]. Factors such as alcohol, drugs, heavy metals, and high-fat diet are now identified as inducers of hepatic oxidative stress [8]. In liver injury, hepatocytes, the key parenchymal cells, suffer oxidative stress the most. In response to oxidative stress, Kupffer cells produce a variety of cytokines which contribute to hepatocyte apoptosis [9]. Oxidative stress also induces proliferation of stellate cells and collagen synthesis, thus promoting fibrosis and cirrhosis. In response to overwhelming oxidative stress, there is a significant use of antioxidant proteins, along with an increase in lipid peroxidation. However, to maintain redox homeostasis, hepatocytes have a sophisticated antioxidant system comprising antioxidant proteins, enzymes, and transcription factors to combat oxidative stress. Hence, regulation of hepatic oxidative stress can play a critical role in the treatment of various liver diseases.

Nuclear erythroid 2-related factor 2 (Nrf2), a transcription factor of the cap'n'collar basic leucine zipper family [10], is a key regulator of oxidative stress in numerous cell types including hepatocytes [11-16]. Nrf2 is primarily regulated 
by Kelch-like ECH-associated protein 1 (Keap1), a substrate adaptor for a cul3-containing E3 ubiquitin ligase [17]. In the absence of oxidative stress, Nrf2 is located in the cytoplasm where it interacts with Keapl and is rapidly degraded by the ubiquitin-proteasome pathway $[18,19]$. However, under oxidative stress, phosphorylation of Nrf2 leads to its dissociation from Keapl and subsequent translocation to the nucleus $[14,15,19]$. Herein, it binds to antioxidant response element (ARE) sequences and, in partnership with other nuclear proteins, enhances the transcription of ARE-responsive genes such as hemeoxygenase-1 (HO-1), NAD(P)H:quinone oxidoreductase 1 (NQO1), glutathione-S-transferases (GST), glutamate-cysteine ligase modifier subunit (GCLM), glutathione peroxidase (GPX), and glutamate-cysteine ligase catalytic subunit (GCLC) to mount strong antioxidant and cytoprotective responses [20, 21].

Numerous studies have shown that natural products regulate oxidative stress in the liver by modulating Nrf2ARE pathway to render hepatoprotective effect. This review discusses the importance of Nrf2-ARE in regulating liver injury and the role of natural product based activators (phytochemicals) of Nrf2-ARE pathway in treating liver injury (Table 1).

\section{Nrf2 Signaling in Acetaminophen-Induced Hepatotoxicity}

APAP is one of the most widely used over-the-counter analgesics. APAP is safe when taken at therapeutic doses but causes severe liver injury when ingested in higher-than-recommended doses. Acute liver failure due to APAP overdose is associated with high mortality [22]. In the United States, the incidence of APAP overdose is over 100,000 cases each year [23]. When ingested in therapeutic doses, APAP is mainly metabolized by sulfation and glucuronidation, leaving only a small fraction to be metabolized by cytochrome p4502E1 (CYP2E1) [24]. However, upon overdose, glucuronidation and sulfation pathways get saturated leading to APAP's metabolism by CYP2E1, resulting in generation of N-acetyl-p-benzoquinone imine (NAPQI), a toxic intermediate metabolite capable of inducing oxidative stress. NAPQI depletes hepatic glutathione (GSH) content and binds to cellular proteins, with subsequent activation of c-Jun N-terminal kinase (JNK). JNK activation results in overproduction of reactive oxygen species (ROS) and reactive nitrogen species (RNS) resulting in mitochondrial dysfunction and hepatocyte death [25-27]. Within 60 minutes of administration of APAP in mice, there is an increase in Nrf2 nuclear translocation in hepatocytes with concomitant increase in the expression of several Nrf2 target genes [28, 29]. Studies using Nrf2-knockout mice showed that even lower doses of APAP could induce mortality due to suppressed GSH synthesis pathway [30]. Contrary to this, hepatocyte-specific deletion of Keapl activates Nrf2 and confers resistance against APAP toxicity [31]. Interestingly, in Nrf2-knockout mice, the elimination of APAP metabolites is also decreased as a result of reduced expression of multidrug resistance proteins (MRPs) [32]. And, in Keapl-knockout mice, MRP expression is increased, which enhanced efflux of APAP metabolites [29].
These observations indicate that, in APAP-induced hepatotoxicity, Nrf2 modulates injury not only by regulating antioxidant response but also by modulating APAP elimination.

Protein tyrosine phosphorylation is pivotal in cell survival. In this context, the balance between tyrosine kinases and phosphatases determines cell fate. One of the protein tyrosine phosphatases, protein tyrosine phosphatase $1 \mathrm{~B}$ (PTP1B), is widely expressed and inactivates many tyrosine kinase family members by dephosphorylation. During APAP toxicity in mice, PTP1B expression is significantly increased. PTP1B deficient mouse hepatocytes are protected against APAP-induced GSH depletion and oxidative stress by prolonged Nrf2 nuclear accumulation [33].

Various classes of phytochemicals have been shown to activate Nrf2 pathway and reduce APAP toxicity (Table 1). Sauchinone, a polyphenol, reduces the impact of APAP overdose by enhancing Nrf2 phosphorylation via protein kinase $\mathrm{C}-\delta(\mathrm{PKC} \delta)$ and decreasing interaction amongst $\mathrm{Nrf} 2$ and Keap1 [34]. Salvianolic acid B reduces APAP-induced liver injury via phosphoinositide-3-kinase- (PI3K-) and PKCmediated Nrf2 activation, resulting in enhanced HO-1 and GCLC expressions [35]. Sulforaphane (an isothiocyanate found in cruciferous vegetables, namely, cauliflower, broccoli, kale, cole crops, cabbage, collards, brussels sprouts, and mustard) and oleanolic acid (a triterpenoid found in olives) both reduce APAP-induced oxidative stress and liver injury via Nrf2 and related antioxidant gene activation $[36,37]$. A recent study from our laboratory evaluated the hepatoprotective potential of withaferin $\mathrm{A}$, an active ingredient of Withania somnifera. We observed that withaferin A treatment $1 \mathrm{~h}$ after APAP intoxication activates $\mathrm{Nrf} 2$ responsive genes such as NQO1 and GCLC to reduce oxidative stress and subsequent liver injury [38]. An in vitro study, using rat hepatocytes, reported that ginsenoside $\operatorname{Rg} 3$ (a ginseng saponin) upregulates antioxidant genes (GCLC, GCLM) and basolateral MRPs via Nrf2 activation [39].

Currently, NAC is the only FDA-approved antidote for APAP hepatotoxicity and is most effective within 8-10 h after APAP overdose. Various studies that utilized phytochemicals to reduce APAP toxicity provide a strong proof of concept that naturally existing activators of $\mathrm{Nrf} 2$ can be used to reduce APAP-induced hepatotoxicity. However, these studies have to be interpreted carefully. Many studies have used a preventive experimental strategy, where the phytochemical was administered before inducing APAP overdose, or simultaneously, both unlikely clinical scenarios; patients seek care after APAP overdose. Moreover, such strategies suggest that phytochemicals may interfere with APAP metabolism by suppressing CYP2E1 activity and preventing generation of NAPQI, thus making the interpretation of these studies difficult $[40,41]$. In our recent work, we employed an experimental strategy that was clinically relevant, that is, administering WA $1 \mathrm{~h}$ after APAP overdose, which provides sufficient time for APAP's metabolism into NAPQI and generation of protein adducts to adequately mimic clinical APAP hepatotoxicity in humans $[38,42]$. Therefore, additional studies that not only employ clinically relevant strategies but also use a combination of Nrf2 activators and NAC to combat APAP toxicity are warranted. 
TABLE 1: Various Nrf2 activator phytochemicals and their role in liver injury.

\begin{tabular}{|c|c|c|c|c|}
\hline Phytochemicals & Effective doses & $\begin{array}{l}\text { Experimental procedure (injury } \\
\text { model) }\end{array}$ & Outcomes & References \\
\hline \multicolumn{5}{|l|}{ Acetaminophen toxicity } \\
\hline Ginsenoside Rg3 & $3 \mu \mathrm{g} / \mathrm{mL}$ & $\begin{array}{l}\text { Rat hepatocytes treated with } \\
200 \mu \mathrm{M} \text { NAPQI }\end{array}$ & $\begin{array}{l}\text { Repletion of GSH content and enhanced } \\
\text { expression of Mrp expression }\end{array}$ & [39] \\
\hline Oleanolic acid & $90 \mathrm{mg} / \mathrm{kg}$ & $\begin{array}{l}\text { Mice injected with } 330 \mu \mathrm{mol} / \mathrm{kg} \\
\text { APAP into the right femoral vein }\end{array}$ & $\begin{array}{l}\text { Enhanced antioxidant response to reduce } \\
\text { hepatocyte necrosis }\end{array}$ & {$[37]$} \\
\hline Salvianolic acid B & 25 and $50 \mathrm{mg} / \mathrm{kg}$ & $\begin{array}{l}\text { Mice treated with single dose of } \\
300 \mathrm{mg} / \mathrm{kg} \text { APAP (i.g.) }\end{array}$ & $\begin{array}{l}\text { Antioxidant response and phase II enzyme } \\
\text { induction via activation of PI3K/Akt and } \\
\text { PKC signaling to reduce liver injury }\end{array}$ & {$[35]$} \\
\hline Sauchinone & $30 \mathrm{mg} / \mathrm{kg}$ & $\begin{array}{l}\text { Mice treated with single dose of } \\
500 \mathrm{mg} / \mathrm{kg} \text { APAP (i.p.) }\end{array}$ & $\begin{array}{l}\text { Induction of antioxidant genes to reduce } \\
\text { hepatocyte necrosis }\end{array}$ & {$[34]$} \\
\hline Oleanolic acid & $5 \mathrm{mg} / \mathrm{kg}$ & $\begin{array}{l}\text { Mice treated with single dose of } \\
300 \mathrm{mg} / \mathrm{kg} \text { APAP (i.p.) }\end{array}$ & $\begin{array}{l}\text { Reduction of ROS generation, GSH } \\
\text { depletion, and lipid peroxidation coupled } \\
\text { with upregulation of antioxidant genes }\end{array}$ & {$[36]$} \\
\hline Withaferin A & $40 \mathrm{mg} / \mathrm{kg}$ & $\begin{array}{l}\text { Mice treated with single dose of } \\
250 \mathrm{mg} / \mathrm{kg} \text { APAP (i.p.) }\end{array}$ & $\begin{array}{l}\text { Reduced hepatocyte injury by reducing GSH } \\
\text { depletion }\end{array}$ & {$[38]$} \\
\hline \multicolumn{5}{|l|}{ Inflammatory injury } \\
\hline Ellagic acid & 5,10 , and $20 \mathrm{mg} / \mathrm{kg}$ & $\begin{array}{l}\text { Mice treated with single dose of } \\
800 \mathrm{mg} / \mathrm{kg} \mathrm{Gal}+50 \mu \mathrm{g} / \mathrm{kg} \text { LPS (i.p.) }\end{array}$ & $\begin{array}{l}\text { Reduced LPS/GalN-induced NF- } \kappa \text { B } \\
\text { activation and increased antioxidant genes }\end{array}$ & {$[43]$} \\
\hline Linalool & $\begin{array}{l}10,20, \text { and } \\
40 \mathrm{mg} / \mathrm{kg}\end{array}$ & $\begin{array}{l}\text { Mice treated with single dose of } \\
800 \mathrm{mg} / \mathrm{kg} \mathrm{Gal}+50 \mu \mathrm{g} / \mathrm{kg} \text { LPS (i.p.) }\end{array}$ & $\begin{array}{l}\text { Reduced LPS/GalN-induced NF- } \kappa \mathrm{B} \\
\text { activation and induction of cytoprotective } \\
\text { genes }\end{array}$ & {$[44]$} \\
\hline Mangiferin & 5,10 , and $20 \mathrm{mg} / \mathrm{kg}$ & $\begin{array}{l}\text { Mice treated with single dose of } \\
800 \mathrm{mg} / \mathrm{kg} \mathrm{Gal}+50 \mu \mathrm{g} / \mathrm{kg} \text { LPS (i.p.) }\end{array}$ & $\begin{array}{l}\text { Reduced liver injury by activating } \\
\text { antioxidant pathway and inhibiting NLRP3 } \\
\text { inflammasome activation }\end{array}$ & {$[45]$} \\
\hline Oroxylin A & $\begin{array}{l}15,30, \text { and } \\
60 \mathrm{mg} / \mathrm{kg}\end{array}$ & $\begin{array}{l}\text { Mice treated with single dose of } \\
800 \mathrm{mg} / \mathrm{kg} \mathrm{Gal}+50 \mu \mathrm{g} / \mathrm{kg} \text { LPS (i.p.) }\end{array}$ & $\begin{array}{l}\text { Decreased liver injury by activating } \\
\text { antioxidant genes and inhibiting TLR4 } \\
\text { signaling-mediated inflammation }\end{array}$ & {$[46]$} \\
\hline \multicolumn{5}{|l|}{ Chemical toxicity } \\
\hline Tungtungmadic acid & 5 and $20 \mu \mathrm{M}$ & $\begin{array}{l}\text { Hepalc1c7 cells treated with } 250 \mu \mathrm{M} \\
\text { t-BHP }\end{array}$ & $\begin{array}{l}\text { HO-1 induction via the PI3K/Akt signaling } \\
\text { pathway to reduce hepatocyte death }\end{array}$ & {$[47]$} \\
\hline Antcin C & $\begin{array}{l}20 \mu \mathrm{M} \text { in cells, } \\
100 \mathrm{mg} / \mathrm{kg} \text { in mice }\end{array}$ & $\begin{array}{l}\text { HepG2 cells treated with } 10 \mathrm{mM} \\
\text { AAPH, mice treated with single } \\
\text { dose of } 80 \mathrm{mg} / \mathrm{kg} \text { AAPH (i.p.) }\end{array}$ & $\begin{array}{l}\text { Induction of antioxidant response via } \\
\text { increase of JNK1/2 and PI3K/Akt activities }\end{array}$ & {$[48]$} \\
\hline Butein and phloretin & $\begin{array}{l}25 \mu \mathrm{M} \text { in vitro, } \\
30 \mathrm{mg} / \mathrm{kg} \text { in vivo }\end{array}$ & $\begin{array}{l}\text { Mouse hepatocytes treated with } \\
0.5 \mathrm{mM} \text { t-BHP, rats treated with } \\
\text { single dose of } 1 \mathrm{~mL} / \mathrm{kg} \mathrm{CCl}_{4} \text { (i.p.) }\end{array}$ & $\begin{array}{l}\text { Upregulation of HO- } 1 \text { and GCLC expression } \\
\text { through ERK2 pathway }\end{array}$ & [49] \\
\hline Carthamus red & 10 and $20 \mathrm{mg} / \mathrm{kg}$ & $\begin{array}{l}\text { Mice treated with two doses of } \\
2 \mathrm{~mL} / \mathrm{kg} \mathrm{CCl}_{4} \text {-olive oil mixture }(1: 1)\end{array}$ & $\begin{array}{l}\text { Upregulation of Nrf2, GST } \alpha \text {, and NQO1 } \\
\text { expressions associated with decreased } \\
\text { hepatocyte injury and ALT levels }\end{array}$ & {$[50]$} \\
\hline Curcumin & $200 \mathrm{mg} / \mathrm{kg}$ & $\begin{array}{l}\text { Mice treated with single dose of } \\
20 \mathrm{mg} / \mathrm{kg} \text { DEN (i.p.) }\end{array}$ & $\begin{array}{l}\text { Nrf2-mediated HO-1 induction and } \\
\text { amelioration of hepatocyte injury }\end{array}$ & {$[51]$} \\
\hline Diallyl disulfide & 50 and $100 \mathrm{mg} / \mathrm{kg}$ & $\begin{array}{l}\text { Rats treated with single dose of } \\
2 \mathrm{~mL} / \mathrm{kg} \mathrm{CCl}_{4} \text { (i.g.) }\end{array}$ & $\begin{array}{l}\text { Induction of antioxidant and detoxifying } \\
\text { enzyme activities and suppressing of } \\
\text { inflammatory cytokines production by } \\
\text { reducing NF- } \kappa \text { B activation }\end{array}$ & {$[52,53]$} \\
\hline Ginsenoside Rg1 & 20 and $40 \mathrm{mg} / \mathrm{kg}$ & $\begin{array}{l}\text { Rats treated with } 2 \mathrm{~mL} / \mathrm{kg} \text { of } 50 \% \\
\mathrm{CCl}_{4} \text { (s.c.) twice a week for } 8 \text { weeks }\end{array}$ & $\begin{array}{l}\text { Reduced liver fibrosis by augmented } \\
\text { antioxidant systems }\end{array}$ & {$[54]$} \\
\hline Glycyrrhetinic acid & 25 and $50 \mathrm{mg} / \mathrm{kg}$ & $\begin{array}{l}\text { Mice treated with } 6.4 \mathrm{~g} / \mathrm{kg} \mathrm{CCl}_{4} \\
\text { (s.c.) for } 30 \text { days }\end{array}$ & $\begin{array}{l}\text { Enhanced antioxidant genes expression to } \\
\text { reduce hepatocyte injury }\end{array}$ & {$[55]$} \\
\hline Hesperidin & 40 and $80 \mu \mathrm{M}$ & $\begin{array}{l}\text { LO-2 cells treated with } 150 \mu \mathrm{M} \\
\text { t-BHP }\end{array}$ & $\begin{array}{l}\text { ERK-mediated nuclear translocation of } \mathrm{Nrf} 2 \\
\text { to induce HO-1 gene expression and } \\
\text { antioxidant response }\end{array}$ & {$[56]$} \\
\hline
\end{tabular}


TABle 1: Continued.

\begin{tabular}{|c|c|c|c|c|}
\hline Phytochemicals & Effective doses & $\begin{array}{l}\text { Experimental procedure (injury } \\
\text { model) }\end{array}$ & Outcomes & References \\
\hline Isoorientin & $5 \mu \mathrm{g} / \mathrm{mL}$ & $\begin{array}{l}\text { HepG2 cells treated with } 200 \mu \mathrm{M} \\
\text { t-BHP }\end{array}$ & $\begin{array}{l}\text { Upregulation of antioxidant enzyme } \\
\text { expression through PI3K/Akt pathway }\end{array}$ & {$[57]$} \\
\hline Naringenin & $50 \mathrm{mg} / \mathrm{kg}$ & $\begin{array}{l}\text { Rats treated with } 2 \mathrm{~mL} / \mathrm{kg} \\
\mathrm{CCl}_{4} \text {-olive oil mixture }(1: 1) \text { on days } \\
2 \text { and } 5 \text { (i.p.) }\end{array}$ & $\begin{array}{l}\text { Increase in Nrf } 2 \text { and } \mathrm{HO}-1 \text { expression to } \\
\text { reduce liver injury }\end{array}$ & {$[58]$} \\
\hline Oxyresveratrol & $\begin{array}{l}10 \mu \mathrm{M} \text { for in vitro } \\
\text { study, } 10 \text { and } \\
30 \mathrm{mg} / \mathrm{kg} \text { for in } \\
\text { vivo study }\end{array}$ & $\begin{array}{l}200 \mu \mathrm{M} \text { t-BHP treatment to HepG2 } \\
\text { cells, ice treated with single dose of } \\
0.5 \mathrm{~mL} / \mathrm{kg} \mathrm{CCl}_{4} \text { (i.p.) }\end{array}$ & $\begin{array}{l}\text { ERK phosphorylation-mediated induction } \\
\text { of antioxidant pathway to protect } \\
\text { hepatocytes against oxidative stress, } \\
\text { mitochondrial damage, and resultant cell } \\
\text { death }\end{array}$ & {$[59]$} \\
\hline Puerarin & $100 \mu \mathrm{M}$ & $\begin{array}{l}500 \mu \mathrm{M} \text { t-BHP treatment to } \\
\text { Hepalc1c7 and HepG2 cells }\end{array}$ & $\begin{array}{l}\text { Augmentation of cellular antioxidant } \\
\text { defenses through Nrf2-dependent HO-1 } \\
\text { induction via PI3K pathway }\end{array}$ & {$[60]$} \\
\hline Resveratrol & 50 and $75 \mu \mathrm{M}$ & $\begin{array}{l}\text { Primary rat hepatocytes treated } \\
\text { with } 500 \mu \mathrm{M} \text { t-BHP }\end{array}$ & $\begin{array}{l}\text { Reduced hepatocyte death by improving } \\
\text { antioxidant status }\end{array}$ & {$[61]$} \\
\hline Schisandrin B & $15 \mu \mathrm{M}$ & $\begin{array}{l}\text { AML12 cells treated with } 20 \mu \mathrm{M} \\
\text { menadione for } 1 \mathrm{~h}\end{array}$ & $\begin{array}{l}\text { Induction of ERK/Nrf2 signaling to enhance } \\
\text { glutathione-mediated antioxidant response } \\
\text { to protect hepatocytes against } \\
\text { menadione-induced apoptosis }\end{array}$ & {$[62]$} \\
\hline \multicolumn{5}{|l|}{ Metal toxicity } \\
\hline Curcumin & $200 \mathrm{mg} / \mathrm{kg}$ & $\begin{array}{l}\text { Exposure of mice to } \mathrm{NaAsO}_{2} \\
(100 \mathrm{mg} / \mathrm{L}) \text { in drinking water }\end{array}$ & $\begin{array}{l}\text { Induction of antioxidant genes and } \\
\text { enhanced methylation and elimination of } \\
\text { arsenic }\end{array}$ & {$[63]$} \\
\hline Lutein & $40 \mathrm{mg} / \mathrm{kg}$ & $\begin{array}{l}\text { Mice treated with } 4 \mathrm{mg} / \mathrm{kg} \mathrm{As}_{2} \mathrm{O}_{3} \\
\text { (i.g.) }\end{array}$ & $\begin{array}{l}\text { Reduced liver injury by induction of } \\
\text { antioxidant response }\end{array}$ & {$[64]$} \\
\hline S-Allylcysteine & $100 \mathrm{mg} / \mathrm{kg}$ & $\begin{array}{l}\text { Mice treated with single dose of } \\
17 \mathrm{mg} / \mathrm{kg} \mathrm{K}_{2} \mathrm{Cr}_{2} \mathrm{O}_{7} \text { (s.c.) }\end{array}$ & $\begin{array}{l}\text { Induction of antioxidant response to reduce } \\
\text { liver injury }\end{array}$ & {$[65]$} \\
\hline \multicolumn{5}{|l|}{ Alcohol toxicity } \\
\hline Lucidone & 1,5 , and $10 \mu \mathrm{g} / \mathrm{mL}$ & $\begin{array}{l}\text { HepG2 cells treated with } 100 \mathrm{mM} \\
\text { ethanol }\end{array}$ & $\begin{array}{l}\text { Induction of HO-1 via Nrf2 signaling } \\
\text { pathway to enhance antioxidant response }\end{array}$ & {$[66]$} \\
\hline Quercetin & $100 \mu \mathrm{M}$ & $\begin{array}{l}\text { Primary human hepatocytes treated } \\
\text { with } 100 \mathrm{mM} \text { ethanol }\end{array}$ & $\begin{array}{l}\text { ERK- and p38-mediated Nrf2 nuclear } \\
\text { translocation and subsequent induction of } \\
\text { HO-1 activity }\end{array}$ & {$[67,68]$} \\
\hline Quercetin & $50 \mu \mathrm{M}$ & $\begin{array}{l}\text { LO- } 2 \text { cells treated with } 100 \mathrm{mM} \\
\text { ethanol }\end{array}$ & $\begin{array}{l}\text { Preventing hepatotoxicity by inducing p } 62 \\
\text { expression and induction of antioxidant } \\
\text { response }\end{array}$ & {$[69]$} \\
\hline Sulforaphane & $50 \mathrm{mg} / \mathrm{kg}$ & $\begin{array}{l}\text { Mice treated with } 3 \mathrm{~g} / \mathrm{kg} \text { ethanol } \\
(30 \%) \text { for } 5 \text { days (i.g.) }\end{array}$ & $\begin{array}{l}\text { Decreased hepatocyte lipid accumulation } \\
\text { and injury without altering CYP2E1 } \\
\text { expression }\end{array}$ & {$[70]$} \\
\hline \multicolumn{5}{|c|}{ Nonalcoholic steatohepatitis } \\
\hline Baicalein & $10 \mathrm{mg} / \mathrm{kg}$ & Rats fed with MCD diet for 8 weeks & $\begin{array}{l}\text { Reduction in inflammation and oxidative } \\
\text { hepatocyte injury }\end{array}$ & {$[71]$} \\
\hline Curcumin & $50 \mathrm{mg} / \mathrm{kg}$ & Rats fed with HFD for 6 weeks & $\begin{array}{l}\text { Reduced hepatocyte lipid accumulation and } \\
\text { improved insulin resistance and } \\
\text { anti-inflammatory and antioxidant effects }\end{array}$ & {$[72]$} \\
\hline Gastrodin & $\begin{array}{l}10,20, \text { and } \\
50 \mathrm{mg} / \mathrm{kg}\end{array}$ & $\begin{array}{l}\text { HL-7702 cells treated with } 0.6 \mathrm{mM} \\
\text { of OA for } 24 \mathrm{~h} \text {, mice fed with HFD } \\
\text { for } 10 \text { weeks }\end{array}$ & $\begin{array}{l}\text { AMPK-mediated induction of Nrf2 pathway } \\
\text { to enhance expression of antioxidant } \\
\text { enzymes }\end{array}$ & {$[73]$} \\
\hline Lycopene & $15 \mathrm{mg} / \mathrm{kg}$ & $\begin{array}{l}\text { Mice fed with HFD for the next } 6 \\
\text { weeks following a single dose of } \\
30 \mathrm{mg} / \mathrm{kg} \text { DEN injection }\end{array}$ & $\begin{array}{l}\text { Reduction in hepatocyte injury by induction } \\
\text { of antioxidant pathway along with a } \\
\text { decrease in CY2E1 expression }\end{array}$ & {$[74]$} \\
\hline \multicolumn{5}{|c|}{ Cholestatic liver injury } \\
\hline Oleanolic acid & $20 \mathrm{mg} / \mathrm{kg}$ & $\begin{array}{l}\text { Mice treated with } 125 \mathrm{mg} / \mathrm{kg} \mathrm{LCA} \\
\text { (i.p.) }\end{array}$ & $\begin{array}{l}\text { Upregulation of Mrp2, Mrp3, and Mrp4 to } \\
\text { reduce cholestatic liver injury }\end{array}$ & {$[75]$} \\
\hline Oleanolic acid & $20 \mathrm{mg} / \mathrm{kg}$ & Bile duct ligation in mice & $\begin{array}{l}\text { Induction of Mrps and FXR antagonism to } \\
\text { reduce cholestatic liver injury }\end{array}$ & {$[76]$} \\
\hline
\end{tabular}


TABLE 1: Continued.

\begin{tabular}{|c|c|c|c|c|}
\hline Phytochemicals & Effective doses & $\begin{array}{l}\text { Experimental procedure (injury } \\
\text { model) }\end{array}$ & Outcomes & References \\
\hline Paeoniflorin & $200 \mathrm{mg} / \mathrm{kg}$ & $\begin{array}{l}\text { Rats treated with } 50 \mathrm{mg} / \mathrm{kg} \text { ANIT } \\
\text { for } 4 \text { days (i.g.) }\end{array}$ & $\begin{array}{l}\text { Enhanced GSH synthesis by activating Nrf2 } \\
\text { through PI3K/Akt-dependent pathway }\end{array}$ & {$[8]$} \\
\hline Sulforaphane & $50 \mathrm{mg} / \mathrm{kg}$ & $\begin{array}{l}\text { Mice treated with } 3 \mathrm{~g} / \mathrm{kg} \text { ethanol } \\
(30 \%) \text { for } 5 \text { days (i.g.) }\end{array}$ & $\begin{array}{l}\text { Decreased hepatocyte lipid accumulation } \\
\text { and injury without altering CYP2E1 } \\
\text { expression }\end{array}$ & {$[70]$} \\
\hline Sulforaphane & $25 \mathrm{mg} / \mathrm{kg}$ & Bile duct ligation in mice & $\begin{array}{l}\text { Antifibrotic response by inhibition of } \\
\text { TGF- } \beta / \text { Smad signaling pathway }\end{array}$ & {$[77]$} \\
\hline
\end{tabular}

AAPH: 2,2' -azobis(2-amidinopropane) dihydrochloride; MCD: methionine and choline deficient; $\mathrm{CCl}_{4}$ : carbon tetrachloride; DEN: dimethylnitrosamine; HFD: high-fat diet; Gal: galactosamine; LPS: lipopolysaccharide; OA: oleic acid; NAPQI: N-acetylbenzoquinoneimine; i.p.: intraperitoneal; s.c.: subcutaneous; i.g.: intragastric; t-BHP: tert-butyl hydroperoxide; APAP: acetaminophen; LCA: lithocholic acid; ANIT: alpha-naphthylisothiocyanate; Nrf2: nuclear factor (erythroid-derived 2)-like 2; JNK1/2: c-Jun N-terminal kinases 1/2; PI3K/AKT: phosphoinositide 3-kinase/protein kinase B; HO-1: heme oxygenase-1; GCLC: glutamate-cysteine ligase catalytic subunit; ALT: alanine transaminase; GST: glutathione S-transferase; NQO1: NAD(P)H quinone dehydrogenase 1; AMPK: $5^{\prime}$ AMP-activated protein kinase; GSH: glutathione; CYP2E1: cytochrome P450 2E1; NLRP3: NLR family pyrin domain containing 3; Mrp: multidrug resistanceassociated protein; TLR4: Toll-like receptor 4; Keapl: Kelch-like ECH-associated protein 1.

\section{Acute Inflammatory Liver Injury and Nrf2}

Inflammation-mediated repeated liver injury may progress to chronic fibrosis and cirrhosis. Studies in various models of liver injury have shown that Nrf2 plays a role in inflammation-induced liver injury. Lack of an active Nrf2 signaling pathway results in severe inflammation-induced oxidative stress. Concanavalin A (ConA) treatment to mice activates and recruits T-lymphocytes and causes severe inflammation and hepatocyte apoptosis [78, 79]. Following intravenous injection of ConA, Nrf2-KO mice develop increased liver injury compared to WT mice. Hepatocytespecific conditional Keapl-null mice and WT mice pretreated with three daily doses of CDDO-Im, a Nrf2 activator, had significantly reduced ConA-induced injury compared to Nrf2KO mice. Similarly, in response to LPS/galactosamine treatment, Nrf2-null mice had increased liver injury compared to WT mice, and, predictably, hepatocyte-specific Keap1-KO mice were protected [80]. These results highlight the importance of Nrf2-mediated regulation of cytokine-dependent hepatocyte apoptosis [81]. In another study, investigators used a short interfering RNA (siRNA) against Keap1 to assess the role of Nrf2 in liver injury; mice were injected with Keap1- or luciferase (control)-siRNA-containing liposomes via the tail vein and, after 48 hours, with ConA. Silencing of hepatic Keapl attenuated ConA-induced inflammationassociated liver damage [82].

Mangiferin and oroxylin A, the naturally occurring flavonoids, reduce LPS/galactosamine-induced liver injury in mice by reducing oxidative stress and inflammation. Mangiferin enhanced Nrf2/HO-1 signaling and inhibited NLR family, pyrin domain containing 3 (NLRP3) inflammasome [45]. Oroxylin A activated Nrf2 signaling and inhibited Toll-like receptor 4 (TLR4) signaling [46]. Linalool, a major volatile component of essential oils in several aromatic plant species, and ellagic acid (EA), a naturally occurring plant phenol found in certain fruits, nuts, and vegetables, have been shown to possess anti-inflammatory and antioxidant properties. Both of these phytochemicals reduced LPS/galactosamineinduced hepatocyte apoptosis by activating hepatocyte
Nrf2-mediated antioxidant response and inflammation by suppressing NF-kB pathway in the liver [43, 44]. These phytochemicals, which reduce both oxidative stress and inflammation, are potential agents for the treatment of fulminant hepatitis in humans.

\section{Role of Nrf2 in Chemical-Induced Liver Injury}

Carbon tetrachloride $\left(\mathrm{CCl}_{4}\right)$ is a potent hepatotoxin known to cause centrilobular hepatic necrosis in rodent models of liver fibrosis. Acute administration of $\mathrm{CCl}_{4}$ at higher doses causes severe hepatocyte necrosis, while chronic administration at lower doses is used to induce hepatic fibrosis [40]. However, this model is often criticized because it affects the central zone of the hepatic acinus and some nonmetabolized intermediates of $\mathrm{CCl}_{4}$ can induce lung and kidney injury [83]. In hepatocytes, cytochrome $\mathrm{P} 450$ metabolizes $\mathrm{CCl}_{4}$ to trichloromethyl free radicals $\left(\mathrm{CCl}_{3}{ }^{\circ}\right.$ and/or $\left.\mathrm{CCl}_{3} \mathrm{OO}{ }^{\circ}\right)$, which subsequently leads to generation of $\operatorname{ROS}\left({ }^{\circ} \mathrm{O}_{2}{ }^{-}, \mathrm{H}_{2} \mathrm{O}_{2}\right.$, and $\left.{ }^{\circ} \mathrm{OH}\right)$ [84]. Chemical hepatotoxins such as bromobenzene, $\mathrm{CCl}_{4}$, and furosemide trigger hepatic Nrf2 nuclear translocation and Nrf2-regulated gene expression [85]. In Nrf2-deficient mice, repair of liver injury after a single treatment with $\mathrm{CCl}_{4}$ was severely delayed [86]. Similarly, after 1-bromopropane exposure, compared to WT mice, Nrf2-knockout mice had increased liver injury with reduced antioxidant response [87].

Lee and colleagues studied the efficacy of diallyl disulfide (DADS), a secondary component derived from garlic, in amelioration of $\mathrm{CCl}_{4}$-induced acute liver injury. Pretreatment with DADS (50 and $100 \mathrm{mg} / \mathrm{kg} /$ day) significantly activated Nrf2 expression and antioxidant and phase II enzymes to reduce liver injury $[52,53]$. Oxyresveratrol (OXY), an antioxidant present in mulberry fruits and twigs, ameliorated tertbutyl hydroperoxide- (t-BHP-) and $\mathrm{CCl}_{4}$-induced hepatotoxicity by reducing oxidative stress possibly via extracellular signal-regulated kinase- (ERK-) mediated Nrf2 activation in hepatocytes [59]. Other flavonoids such as carthamus red and naringenin also activate Nrf2 signaling to reduce $\mathrm{CCl}_{4}$ 
injury in rats [50, 58]. Glycyrrhetinic acid, a triterpenoid, and ginsenoside Rgl, a phytoestrogen, ameliorated $\mathrm{CCl}_{4}$-induced liver fibrosis via nuclear Nrf2 translocation and upregulation of antioxidant enzymes to reduce oxidative stress $[54,55]$.

Several other compounds such as $2,2^{\prime}$-azobis(2-amidinopropane) dihydrochloride (AAPH), menadione (MEN), and carboxymethyllysine (CML) induce free radical-induced damage, and each of them is a potent inducer of hepatotoxicity. Phytocompounds such as antcin C [48], dimerumic acid [88], and schisandrin $B$ [62] have been shown to ameliorate AAPH-, CML-, and MEN-induced liver injury, respectively. Dimethylnitrosamine (DMN) is a semivolatile organic chemical produced as a byproduct of industrial processes and is also known to cause oxidative liver injury. In DMNadministered rats, oral administration of curcumin enhanced nuclear translocation and ARE binding of Nrf2, producing robust antioxidant response thereby reducing hepatotoxicity [51].

In laboratories, t-BHP is a commonly used inducer of oxidative stress in vitro $[53,89,90]$. In hepatocytes, t-BHP is metabolized by CYP450 into free radical intermediates such as $t$-butoxyl and $t$-methyl radicals [91], which induce lipid peroxidation and glutathione (GSH) depletion resulting in organelle damage and cell death [92]. Hence, t-BHPinduced hepatotoxicity model is widely used for evaluating merits of Nrf2-ARE signaling in hepatocytes. Various plant flavonoids possess excellent antioxidant potential and confer hepatoprotection. Flavonoids such as hesperidin, butein, and phloretin reduce t-BHP toxicity in hepatocytes via ERK phosphorylation $[49,56]$, whereas another member of the same class, isoorientin, induces Nrf2 activation via PI3K/Akt pathway [57]. Additionally, phenolics such as 3-caffeoyl, 4dihydrocaffeoyl quinic acid, and resveratrol ameliorate tBHP-induced hepatocyte oxidative stress via Nrf2 induction [47, 61]. Another phytoestrogen, puerarin, reduces t-BHPinduced oxidative stress in Hepalclc7 cells via PI3K/Akt pathway [60]. These findings underscore the importance of phytochemicals-mediated regulation of $\mathrm{Nrf} 2$ activity in diverse models of hepatocyte toxicity, but many of these results need to be validated in animal models of liver injury.

\section{Metal Toxicity and Nrf2}

Heavy metals, such as cadmium (Cd), chromium (Cr), copper $(\mathrm{Cu})$, lead $(\mathrm{Pb})$, and mercury $(\mathrm{Hg})$, pose health concerns via exposure through water, food, or environmental waste [93]. In experimental models, these heavy metals cause severe oxidative stress and hepatotoxicity. Since these metals induce ROS, it is conceivable that they might induce Nrf2 activation in hepatocytes. A study using Nrf2-KO, Keap1-KO, and hepatocyte-specific Keapl-knockout mice showed that Cd caused extensive liver damage in Nrf2-null mice, whereas Keap1-KO and Keap1-HKO mice were resistant to injury [94].

Arsenic (a metalloid) is a known pollutant for drinking water and has provoked public health concern worldwide. Arsenic modulates Nrf2 signaling in vivo and in vitro [46, 95, 96]. Lutein (a carotenoid) and curcumin (a diarylheptanoid) have been shown to reduce arsenic toxicity via Nrf2 activation and subsequent antioxidant gene expression $[63,64]$.
Additionally, in mice, curcumin promoted methylation of arsenic and accelerated its excretion [63].

Several studies demonstrated that $\mathrm{Cr}(\mathrm{VI})$ induces hepatotoxicity by increasing ROS generation $[97,98]$. In Hepalclc7 cells, $\mathrm{Cr}(\mathrm{VI})$ induces ROS production and in turn triggers activation of Nrf2 pathway [99]. Garlic and its derivative Sallylcysteine (SAC) reduced $\mathrm{Cr}(\mathrm{VI})$-induced hepatotoxicity [65].

In this industrialization era, metal toxicity is a growing concern, and Nrf2 presents a potential target that can be explored to discover novel hepatoprotective agents. These studies suggest that the use of phytochemicals may be helpful in negating the hepatotoxic effects of heavy metals.

\section{Nrf2 and Alcoholic Liver Injury}

Chronic alcohol consumption is known to result in liver injury-associated deaths [100]. Alcohol abuse leads to increased production of ROS, depletion of hepatocytes antioxidant levels, and enhanced oxidative stress [101, 102]. However, it also leads to an increase in Nrf2 mRNA and protein in the livers [103]. Gong and Cederbaum speculated that the increase in Nrf2 expression was dependent on ethanol-mediated induction of CYP2E1. Compared to WT mice, ethanol-administered Nrf2-KO mice had depletion of total and mitochondrial GSH in their livers resulting in increased liver failure and mortality, while ethanol-fed Keap1-HKO mice were protected [104]. Keap1 knockdown in mice, which induces Nrf2 activation, also blunted ethanolmediated increase in serum triglycerides and hepatic free fatty acids [105].

Quercetin (a plant flavonoid), a known antioxidant and free radical scavenger, reduces ethanol toxicity in hepatocytes which is Nrf2-mediated. Quercetin upregulates HO-1 via the MAPK/Nrf2 pathway to confer hepatoprotection [67, 68]. A recent study showed that quercetin interacts with Keap1 and blocks its binding to Nrf2 [69]. Sulforaphane (an isothiocyanate) is a known activator of Nrf2 pathway. Zhou et al. showed that sulforaphane induces Nrf2 activation to reduce lipid accumulation and oxidative stress in hepatocytes, an effect independent of CYP2E1 [70]. Lucidone (a naturally occurring cyclopentenedione in Lindera sp.) reduces ethanolinduced oxidative stress in HepG2 cells [66] by inducing Nrf2-mediated antioxidant response via profound upregulation of HO-1.

Despite its known detrimental effects, alcohol remains a major cause of liver injury. These observations from preclinical studies indicate that targeting Nrf2 has merits in treating alcoholic liver injury. These natural Nrf2 activators need to be studied in clinical settings to determine the impact on alcohol abuse-mediated liver injury burden.

\section{Nrf2 and Nonalcoholic Steatohepatitis}

Nonalcoholic fatty liver disease (NAFLD) is becoming the most common cause of chronic liver disease [106, 107]. In NAFLD, multiple mechanisms operate simultaneously which results in hepatocyte apoptosis, inflammation, and fibrosis, 
that is, nonalcoholic steatohepatitis (NASH) [107, 108]. In $\mathrm{NASH}$, excessive lipid accumulation and subsequent generation of ROS from impaired mitochondrial respiratory chain result in GSH depletion $[109,110]$. It is interesting to note that two research groups showed in mice that high-fat diet (HFD) can increase or decrease hepatic Nrf2 [111]. However, upon HFD feeding, Nrf2-null mice suffered from severe liver injury compared to wild-type mice [112]. Livers of methioninecholine deficient diet- (MCD-) fed Nrf2-knockout mice had higher levels of oxidative stress, iron accumulation, fibrosis, and inflammation than wild-type mice [113-115]. It is suggested that Nrf2 activation protects against NAFLD and NASH also via controlling inflammation [115]. The overall merits of Nrf2-mediated prevention of oxidative damage and progression of NAFLD imply its potential use in patients suffering from NASH.

Studies have shown the beneficial role of phytochemicals in treating NASH in preclinical and clinical settings [116118]. Lycopene (a carotenoid derived from tomato) is shown to reduce HFD-induced steatohepatitis in rats [119]. Wang et al. showed that lycopene-induced inhibition of NASH and hepatocarcinogenesis in rats is partially due to induction of Nrf2 and HO-1 genes [74]. Gastrodin (GSTD, a natural compound isolated from Gastrodia elata BI, a traditional Chinese herbal medicine) ameliorates oxidative stress and proinflammatory response in cellular and animal models of NAFLD. GSTD-induced AMPK activation phosphorylates $\mathrm{Nrf2}$, which in turn enhances its nuclear translocation and expression of antioxidant genes (HO-1 and SOD1) [73]. In rats, baicalein (a flavonoid) has been shown to ameliorate MCD-diet-induced NASH by activating multiple pathways including Nrf2-ARE pathway [71]. Similar results have been reported in studies with curcumin where Nrf2 activation ameliorated hepatotoxicity and reduced NASH [72]. Scientific data available till date indicate that the role of natural compounds in Nrf2 activation and alleviation of NASH in experimental models warrants additional human studies. Owing to the multifactorial nature of $\mathrm{NASH}$, a combination of Nrf2 activator and lipid-lowering drugs may translate into an effective therapeutic strategy.

\section{Nrf2 and Cholestatic Liver Injury}

Cholestasis, a reduction in bile flow, results in a dramatic increase in both liver and serum bile acid concentrations leading to acute liver toxicity, proliferation of bile ducts, and eventually cirrhosis [120]. Bile duct ligated- (BDL-) Nrf2deficient mice showed reduced elimination of bile acids and higher intrahepatic accumulation of toxic bile acids leading to GSH depletion and injury [121, 122]. BDL-Keap1$\mathrm{KO}$ mice had sustained activation of $\mathrm{Nrf} 2$ and increased expression of MRP efflux transporters, detoxifying enzymes, and antioxidant genes $[121,123]$. Interestingly, following BDL, Nrf2-KO mice developed into a cholestatic phenotype but liver injury was not different from WT mice undergoing BDL, suggesting that Nrf2 plays a role in the regulation of bile acid homeostasis in the liver [121]. Nrf2-KO mice treated with lithocholic acid (LCA, a toxic bile acid) compared to wild-type mice had severe multifocal liver necrosis and increased inflammation and serum ALT levels [124].

Ursodeoxycholic acid (UDCA), a secondary bile acid, is reported to be hepatoprotective $[125,126]$. UDCA treatment of WT mice significantly increased nuclear Nrf2 expression and that of hepatic Mrp2, Mrp3, and Mrp4 [127]. In patients with biliary cirrhosis, UDCA treatment enhanced hepatic Nrf2 expression with an upregulated hepatic thioredoxin and thioredoxin reductase 1 expression [128]. These studies indicate a role of $\mathrm{Nrf} 2$ and its activation as a viable target in treating cholestatic liver injury.

Oleanolic acid (OA), a natural triterpenoid, has been shown to reduce LCA- and BDL-induced cholestatic injury in mice $[75,76]$. Protection of both of these models is thought to be due to Nrf2-mediated upregulation of Mrps. However, high doses of $\mathrm{OA}$ induce cholestatic liver injury in mice by downregulation of hepatic transporters and disruption of bile acid uptake and metabolism [129]. Sulforaphane also reduces cholestasis injury in mice by hepatocyte Nrf2 activation [77]. Alpha-naphthylisothiocyanate (ANIT) is used to induce hepatotoxicity in animal models, which mimics druginduced cholestatic hepatic injury in humans [130]. Chen et al. demonstrated that paeoniflorin (a monoterpene glycoside) ameliorates ANIT-induced cholestasis in rats by activating Nrf2 via PI3K/Akt pathway [8]. Since Nrf2 regulates both antioxidant genes and multidrug resistance-associated proteins, it has great implication in treating cholestasis.

\section{In Vitro Nrf2-ARE Pathway Activation by Phytochemicals}

Various hepatocyte cell lines and primary hepatocytes have been used to demonstrate mechanisms of phytochemicalsinduced Nrf2 activation. A handful of phytochemicals have been reported to activate Nrf2 signaling in hepatocytes and related cell lines even in the absence of exogenous oxidative stress stimuli. For example, compared to vehicle, phytochemicals such as isothiocyanate (6-methylthiohexyl isothiocyanate), capsaicinoids (capsaicin), terpenoids (carnosol and maslinic acid), polyphenols (eckol, quercetin, and phloretamide), chalconoids (xanthohumol), and flavonoids (epicatechin) induce Nrf2 activation in hepatocytes [131-139]. Although these studies comprehensively demonstrate the ability of phytochemicals to induce Nrf2 activation in hepatocytes, one of the merits of these compounds under conditions of oxidative stress, both in vitro and in vivo, is the prevailing lacunae, which leaves many questions unanswered.

\section{Cytotoxicity of Phytochemicals}

Consumption of herbal mixtures or bioactive molecules can lead to adverse events as well as hepatotoxicity [140]. Phytochemicals found naturally in many plants, fruits, and vegetables are generally believed to be devoid of major side effects [140]. However, safety studies are lacking and many phytochemicals that are marketed as food supplements have already been shown to have adverse effects. Polyphenols and flavonoids, which are popular for their beneficial 
effects, have been reported to induce adverse events. For example, consumption of polyphenols inhibits nonheme iron absorption and may lead to iron depletion [141]. At higher doses, flavonoids have been reported to act as mutagens, prooxidants, and inhibitors of key enzymes involved in hormone metabolism [142]. Oleanolic acid, which is a known inducer of Nrf2 pathway, has been shown to cause cholestasis at higher doses $[129,143]$.

Medical literature is littered with various reports of herb-induced hepatotoxicity $[144,145]$. For example, black cohosh used for menopausal symptoms can lead to liver failure. We refer the reader to recent articles [146-149]. Safety studies for most phytochemicals discussed here are lacking. The FDA is not authorized to review dietary supplement products for safety and effectiveness before they are marketed (http://www.fda.gov). Hence, there is a big gap in the knowledge regarding the safety profile of phytochemicals and toxicity studies will be needed before they are considered safe for human usage.

\section{Concluding Remarks}

Almost all modes of liver injury are associated with increased oxidative stress and an overwhelmed antioxidant defense system. Since Nrf2 activation is associated with the enhancement of endogenous antioxidant system, it can be an ideal therapeutic target for reducing oxidative stress. Nrf2-ARE pathway boosts hepatocyte antioxidant defense system but may not be able to reduce pathogenesis of liver injury. Hence, a synchronal use of natural Nrf2 activators in combination with other pharmacological agents can be a potential multipronged approach to reduce liver injury. The search for treatments for liver injury is ongoing and potential candidates include whole herbal extracts as well as purified phytochemicals. The literature on preclinical use of phytochemicals to treat various modes of liver injury is ever-growing. However, very few phytochemicals have been tested in clinical settings. Some of the key limitations in this regard are (1) poor choice of experimental models and their clinical relevance, (2) lack of a specific identified mechanism of action, and (3) lack of comprehensive time point data for better interpretation of preclinical findings. These limitations have resulted in weakened significance of these compounds as hepatoprotective agents. Therefore, further studies are needed to explore the full potential of these compounds.

\section{Competing Interests}

The authors declare that there are no competing interests regarding the publication of this paper.

\section{Acknowledgments}

This work was supported by SERB EMR/2015/002001 (Ranjitsinh V. Devkar) and the Medical College of Georgia (Sandeep Khurana).

\section{References}

[1] C. Girish and S. C. Pradhan, "Indian herbal medicines in the treatment of liver diseases: problems and promises," Fundamental and Clinical Pharmacology, vol. 26, no. 2, pp. 180-189, 2012.

[2] R. K. Dhiman and Y. K. Chawla, "Herbal medicines for liver diseases," Digestive Diseases and Sciences, vol. 50, no. 10, pp. 1807-1812, 2005.

[3] A. Kuruvilla, "Herbal formulations as pharmacotherapeutic agents," Indian Journal of Experimental Biology, vol. 40, no. 1, pp. 7-11, 2002.

[4] K.-H. Lu, C.-T. Liu, R. Raghu, and L.-Y. Sheen, "Therapeutic potential of chinese herbal medicines in alcoholic liver disease," Journal of Traditional and Complementary Medicine, vol. 2, no. 2, pp. 115-122, 2012.

[5] H. Farghali, N. K. Canová, and S. Zakhari, "Hepatoprotective properties of extensively studied medicinal plant active constituents: possible common mechanisms," Pharmaceutical Biology, vol. 53, no. 6, pp. 781-791, 2014.

[6] N. Ghosh, R. Ghosh, V. Mandal, and S. C. Mandal, "Recent advances in herbal medicine for treatment of liver diseases," Pharmaceutical Biology, vol. 49, no. 9, pp. 970-988, 2011.

[7] H. Cichoz-Lach and A. Michalak, "Oxidative stress as a crucial factor in liver diseases," World Journal of Gastroenterology, vol. 20, no. 25, pp. 8082-8091, 2014.

[8] Z. Chen, X. Ma, Y. Zhu et al., "Paeoniflorin ameliorates ANITinduced cholestasis by activating Nrf2 through an PI3K/Aktdependent pathway in rats," Phytotherapy Research, vol. 29, no. 11, pp. 1768-1775, 2015.

[9] J. B. Hoek and J. G. Pastorino, "Ethanol, oxidative stress, and cytokine-induced liver cell injury," Alcohol, vol. 27, no. 1, pp. 6368, 2002.

[10] P. Moi, K. Chan, I. Asunis, A. Cao, and Y. W. Kan, "Isolation of NF-E2-related factor 2 (Nrf2), a NF-E2-like basic leucine zipper transcriptional activator that binds to the tandem NF-E2/AP1 repeat of the beta-globin locus control region," Proceedings of the National Academy of Sciences of the United States of America, vol. 91, no. 21, pp. 9926-9930, 1994.

[11] M. Schäfer and S. Werner, "Nrf2-a regulator of keratinocyte redox signaling," Free Radical Biology and Medicine, vol. 88, pp. 243-252, 2015.

[12] I. Buendia, P. Michalska, E. Navarro, I. Gameiro, J. Egea, and R. León, "Nrf2-ARE pathway: an emerging target against oxidative stress and neuroinflammation in neurodegenerative diseases," Pharmacology and Therapeutics, vol. 157, pp. 84-104, 2016.

[13] O. Al-Sawaf, T. Clarner, A. Fragoulis et al., "Nrf2 in health and disease: current and future clinical implications," Clinical Science, vol. 129, no. 12, pp. 989-999, 2016.

[14] H. Zhang, K. J. Davies, and H. J. Forman, "Oxidative stress response and Nrf2 signaling in aging," Free Radical Biology and Medicine, vol. 88, pp. 314-336, 2015.

[15] B. Chen, Y. Lu, Y. Chen, and J. Cheng, "The role of Nrf2 in oxidative stress-induced endothelial injuries," Journal of Endocrinology, vol. 225, no. 3, pp. R83-R99, 2015.

[16] A. Abdul-Aziz, D. J. Macewan, K. M. Bowles, and S. A. Rushworth, "Oxidative stress responses and NRF2 in human leukaemia," Oxidative Medicine and Cellular Longevity, vol. 2015, Article ID 454659, 7 pages, 2015.

[17] M. C. Jaramillo and D. D. Zhang, "The emerging role of the Nrf2-Keap1 signaling pathway in cancer," Genes \& Development, vol. 27, no. 20, pp. 2179-2191, 2013. 
[18] H. K. Bryan, A. Olayanju, C. E. Goldring, and B. K. Park, "The Nrf2 cell defence pathway: Keap1-dependent and -independent mechanisms of regulation," Biochemical Pharmacology, vol. 85, no. 6, pp. 705-717, 2013.

[19] J. W. Kaspar, S. K. Niture, and A. K. Jaiswal, "Nrf2:INrf2 (Keap1) signaling in oxidative stress," Free Radical Biology and Medicine, vol. 47, no. 9, pp. 1304-1309, 2009.

[20] S. P. Reddy, "The antioxidant response element and oxidative stress modifiers in airway diseases," Current Molecular Medicine, vol. 8, no. 5, pp. 376-383, 2008.

[21] C. Espinosa-Diez, V. Miguel, D. Mennerich et al., "Antioxidant responses and cellular adjustments to oxidative stress," Redox Biology, vol. 6, pp. 183-197, 2015.

[22] R. J. Fontana, "Acute liver failure including acetaminophen overdose," Medical Clinics of North America, vol. 92, no. 4, pp. 761-794, 2008.

[23] W. M. Lee, "Acetaminophen and the U.S. Acute Liver Failure Study Group: lowering the risks of hepatic failure," Hepatology, vol. 40, no. 1, pp. 6-9, 2004.

[24] J. R. Mitchell, D. J. Jollow, W. Z. Potter, D. C. Davis, J. R. Gillette, and B. B. Brodie, "Acetaminophen induced hepatic necrosis. I. Role of drug metabolism," Journal of Pharmacology and Experimental Therapeutics, vol. 187, no. 1, pp. 185-194, 1973.

[25] N. Hanawa, M. Shinohara, B. Saberi, W. A. Gaarde, D. Han, and N. Kaplowitz, "Role of JNK translocation to mitochondria leading to inhibition of mitochondria bioenergetics in acetaminophen-induced liver injury," Journal of Biological Chemistry, vol. 283, no. 20, pp. 13565-13577, 2008.

[26] T. R. Knight, Y.-S. Ho, A. Farhood, and H. Jaeschke, "Peroxynitrite is a critical mediator of acetaminophen hepatotoxicity in murine livers: protection by glutathione," Journal of Pharmacology and Experimental Therapeutics, vol. 303, no. 2, pp. 468-475, 2002.

[27] C. Saito, J. J. Lemasters, and H. Jaeschke, "c-Jun N-terminal kinase modulates oxidant stress and peroxynitrite formation independent of inducible nitric oxide synthase in acetaminophen hepatotoxicity," Toxicology and Applied Pharmacology, vol. 246, no. 1-2, pp. 8-17, 2010.

[28] C. E. P. Goldring, N. R. Kitteringham, R. Elsby et al., "Activation of hepatic Nrf2 in vivo by acetaminophen in CD-1 mice," Hepatology, vol. 39, no. 5, pp. 1267-1276, 2004.

[29] L. M. Aleksunes, A. L. Slitt, J. M. Maher et al., "Induction of Mrp3 and Mrp4 transporters during acetaminophen hepatotoxicity is dependent on Nrf2," Toxicology and Applied Pharmacology, vol. 226, no. 1, pp. 74-83, 2008.

[30] K. Chan, X.-D. Han, and Y. W. Kan, "An important function of Nrf2 in combating oxidative stress: detoxification of acetaminophen," Proceedings of the National Academy of Sciences of the United States of America, vol. 98, no. 8, pp. 4611-4616, 2001.

[31] H. Okawa, H. Motohashi, A. Kobayashi, H. Aburatani, T. W. Kensler, and M. Yamamoto, "Hepatocyte-specific deletion of the keap1 gene activates Nrf2 and confers potent resistance against acute drug toxicity," Biochemical and Biophysical Research Communications, vol. 339, no. 1, pp. 79-88, 2006.

[32] S. A. Reisman, I. L. Csanaky, L. M. Aleksunes, and C. D. Klaassen, "Altered disposition of acetaminophen in Nrf2-null and Keap1-knockdown mice," Toxicological Sciences, vol. 109, no. 1, pp. 31-40, 2009.

[33] M. A. Mobasher, A. González-Rodriguez, B. Santamaría et al., "Protein tyrosine phosphatase 1B modulates GSK3b/Nrf2 and
IGFIR signaling pathways in acetaminophen-induced hepatotoxicity," Cell Death and Disease, vol. 4, no. 5, article e626, 2013.

[34] H. Y. Kay, Y. W. Kim, D. H. Ryu, S. H. Sung, S. J. Hwang, and S. G. Kim, "Nrf2-mediated liver protection by sauchinone, an antioxidant lignan, from acetaminophen toxicity through the PKC $\delta$-GSK3 $\beta$ pathway," British Journal of Pharmacology, vol. 163, no. 8, pp. 1653-1665, 2011.

[35] M. Lin, X. Zhai, G. Wang et al., "Salvianolic acid B protects against Acetaminophen hepatotoxicity by inducing Nrf2 and phase II detoxification gene expression via activation of the PI3K and PKC signaling pathways," Journal of Pharmacological Sciences, vol. 127, no. 2, pp. 203-210, 2015.

[36] J. Noh, Y. Kim, J. H. Hwang et al., "Sulforaphane protects against acetaminophen-induced hepatotoxicity," Food and Chemical Toxicology, vol. 80, pp. 193-200, 2015.

[37] S. A. Reisman, L. M. Aleksunes, and C. D. Klaassen, "Oleanolic acid activates Nrf2 and protects from acetaminophen hepatotoxicity via Nrf2-dependent and Nrf2-independent processes," Biochemical Pharmacology, vol. 77, no. 7, pp. 1273-1282, 2009.

[38] R. N. Jadeja, N. H. Urrunaga, S. Dash, S. Khurana, and N. K. Saxena, "Withaferin-a reduces acetaminophen-induced liver injury in mice," Biochemical Pharmacology, vol. 97, no. 1, pp. 122-132, 2015.

[39] S. I. Gum and M. K. Cho, "The amelioration of N-acetylp-benzoquinone imine toxicity by ginsenoside $\mathrm{Rg} 3$ : the role of Nrf2-mediated detoxification and Mrp1/Mrp3 transports," Oxidative Medicine and Cellular Longevity, vol. 2013, Article ID 957947, 11 pages, 2013.

[40] H. Jaeschke, C. D. Williams, M. R. McGill, Y. Xie, and A. Ramachandran, "Models of drug-induced liver injury for evaluation of phytotherapeutics and other natural products," Food and Chemical Toxicology, vol. 55, pp. 279-289, 2013.

[41] H. Jaeschke, M. R. McGill, C. D. Williams, and A. Ramachandran, "Current issues with acetaminophen hepatotoxicity-a clinically relevant model to test the efficacy of natural products," Life Sciences, vol. 88, no. 17-18, pp. 737-745, 2011.

[42] K. Du, M. R. McGill, Y. Xie, M. L. Bajt, and H. Jaeschke, "Resveratrol prevents protein nitration and release of endonucleases from mitochondria during acetaminophen hepatotoxicity," Food and Chemical Toxicology, vol. 81, pp. 62-70, 2015.

[43] L. Gu, W.-S. Deng, Y. Liu et al., "Ellagic acid protects Lipopolysaccharide/D-galactosamine-induced acute hepatic injury in mice," International immunopharmacology, vol. 22, no. 2, pp. 341-345, 2014.

[44] J. Li, X. Zhang, and H. Huang, "Protective effect of linalool against lipopolysaccharide/D-galactosamine-induced liver injury in mice," International Immunopharmacology, vol. 23, no. 2, pp. 523-529, 2014.

[45] C.-W. Pan, Z.-Z. Pan, J.-J. Hu et al., "Mangiferin alleviates lipopolysaccharide and D-galactosamine-induced acute liver injury by activating the Nrf2 pathway and inhibiting NLRP3 inflammasome activation," European Journal of Pharmacology, vol. 770, pp. 85-91, 2016.

[46] H. Huang, X. Zhang, and J. Li, "Protective effect of oroxylin A against lipopolysaccharide and/or D-galactosamine-induced acute liver injury in mice," Journal of Surgical Research, vol. 195, no. 2, pp. 522-528, 2015.

[47] Y. P. Hwang, H. J. Yun, H. K. Chun et al., "Protective mechanisms of 3-caffeoyl, 4-dihydrocaffeoyl quinic acid from Salicornia herbacea against tert-butyl hydroperoxide-induced oxidative damage," Chemico-Biological Interactions, vol. 181, no. 3, pp. 366-376, 2009. 
[48] M. Gokila Vani, K. J. Senthil Kumar, J.-W. Liao et al., "Antcin C from Antrodia cinnamomea protects liver cells against free radical-induced oxidative stress and apoptosis in vitro and in vivo through Nrf2-dependent mechanism," Evidence-Based Complementary and Alternative Medicine, vol. 2013, Article ID 296082, 17 pages, 2013.

[49] Y.-C. Yang, C.-K. Lii, A.-H. Lin et al., "Induction of glutathione synthesis and heme oxygenase 1 by the flavonoids butein and phloretin is mediated through the ERK/Nrf2 pathway and protects against oxidative stress," Free Radical Biology and Medicine, vol. 51, no. 11, pp. 2073-2081, 2011.

[50] S. C. Wu, Y. Yue, H. Tian et al., "Carthamus red from Carthamus tinctorius L. exerts antioxidant and hepatoprotective effect against CCl4-induced liver damage in rats via the Nrf2 pathway," Journal of Ethnopharmacology, vol. 148, no. 2, pp. 570578, 2013.

[51] E. O. Farombi, S. Shrotriya, H.-K. Na, S.-H. Kim, and Y.J. Surh, "Curcumin attenuates dimethylnitrosamine-induced liver injury in rats through Nrf2-mediated induction of heme oxygenase-1," Food and Chemical Toxicology, vol. 46, no. 4, pp. 1279-1287, 2008.

[52] I.-C. Lee, S.-H. Kim, H.-S. Baek et al., "The involvement of Nrf2 in the protective effects of diallyl disulfide on carbon tetrachloride-induced hepatic oxidative damage and inflammatory response in rats," Food and Chemical Toxicology, vol. 63, pp. 174-185, 2014.

[53] I.-C. Lee, S.-H. Kim, H.-S. Baek et al., "Protective effects of diallyl disulfide on carbon tetrachloride-induced hepatotoxicity through activation of Nrf2," Environmental Toxicology, vol. 30, no. 5, pp. 538-548, 2016.

[54] J.-P. Li, Y. Gao, S.-F. Chu et al., "Nrf2 pathway activation contributes to anti-fibrosis effects of ginsenoside Rg1 in a rat model of alcohol- and $\mathrm{CCl}_{4}$-induced hepatic fibrosis," Acta Pharmacologica Sinica, vol. 35, no. 8, pp. 1031-1044, 2014.

[55] S. Chen, L. Zou, L. Li, and T. Wu, "The protective effect of glycyrrhetinic acid on carbon tetrachloride-induced chronic liver fibrosis in mice via upregulation of Nrf2," PLOS ONE, vol. 8, no. 1, Article ID e53662, 2013.

[56] M. Chen, H. Gu, Y. Ye et al., "Protective effects of hesperidin against oxidative stress of tert-butyl hydroperoxide in human hepatocytes," Food and Chemical Toxicology, vol. 48, no. 10, pp. 2980-2987, 2010.

[57] J. H. Lim, H.-S. Park, J.-K. Choi, I.-S. Lee, and J. C. Hyun, "Isoorientin induces $\mathrm{Nrf} 2$ pathway-driven antioxidant response through phosphatidylinositol 3-kinase signaling," Archives of Pharmacal Research, vol. 30, no. 12, pp. 1590-1598, 2007.

[58] M. A. Esmaeili and M. Alilou, "Naringenin attenuates $\mathrm{CCl}_{4}$ induced hepatic inflammation by the activation of an Nrf2mediated pathway in rats," Clinical and Experimental Pharmacology and Physiology, vol. 41, no. 6, pp. 416-422, 2014.

[59] H. Y. Choi, J.-H. Lee, K. H. Jegal, I. J. Cho, Y. W. Kim, and S. C. Kim, "Oxyresveratrol abrogates oxidative stress by activating ERK-Nrf2 pathway in the liver," Chemico-Biological Interactions, vol. 245, pp. 110-121, 2016.

[60] Y. P. Hwang and H. G. Jeong, "Mechanism of phytoestrogen puerarin-mediated cytoprotection following oxidative injury: estrogen receptor-dependent up-regulation of PI3K/Akt and HO-1," Toxicology and Applied Pharmacology, vol. 233, no. 3, pp. 371-381, 2008.

[61] J. A. Rubiolo, G. Mithieux, and F. V. Vega, "Resveratrol protects primary rat hepatocytes against oxidative stress damage: activation of the Nrf2 transcription factor and augmented activities of antioxidant enzymes," European Journal of Pharmacology, vol. 591, no. 1-3, pp. 66-72, 2008.

[62] P. K. Leong, P. Y. Chiu, N. Chen, H. Leung, and K. M. Ko, "Schisandrin B elicits a glutathione antioxidant response and protects against apoptosis via the redox-sensitive ERK/Nrf2 pathway in AML12 hepatocytes," Free Radical Research, vol. 45, no. 4, pp. 483-495, 2011.

[63] S. Gao, X. X. Duan, X. Wang et al., "Curcumin attenuates arsenic-induced hepatic injuries and oxidative stress in experimental mice through activation of Nrf2 pathway, promotion of arsenic methylation and urinary excretion," Food and Chemical Toxicology, vol. 59, pp. 739-747, 2013.

[64] S. Li, Y. Ding, Q. Niu et al., "Lutein has a protective effect on hepatotoxicity induced by arsenic via Nrf2 signaling," BioMed Research International, vol. 2015, Article ID 315205, 2015.

[65] S. Kalayarasan, N. Sriram, A. Sureshkumar, and G. Sudhandiran, "Chromium (VI)-induced oxidative stress and apoptosis is reduced by garlic and its derivative $\mathrm{S}$-allylcysteine through the activation of Nrf2 in the hepatocytes of Wistar rats," Journal of Applied Toxicology, vol. 28, no. 7, pp. 908-919, 2008.

[66] K. J. Senthil Kumar, J.-W. Liao, J.-H. Xiao, M. Gokila Vani, and S.-Y. Wang, "Hepatoprotective effect of lucidone against alcohol-induced oxidative stress in human hepatic HepG2 cells through the up-regulation of HO-1/Nrf-2 antioxidant genes," Toxicology in Vitro, vol. 26, no. 5, pp. 700-708, 2012.

[67] P. Yao, A. Nussler, L. Liu et al., "Quercetin protects human hepatocytes from ethanol-derived oxidative stress by inducing heme oxygenase-1 via the MAPK/Nrf2 pathways," Journal of Hepatology, vol. 47, no. 2, pp. 253-261, 2007.

[68] S. Liu, W. Hou, P. Yao et al., "Heme oxygenase-1 mediates the protective role of quercetin against ethanol-induced rat hepatocytes oxidative damage," Toxicology in Vitro, vol. 26, no. 1, pp. 74-80, 2012.

[69] L.-L. Ji, Y.-C. Sheng, Z.-Y. Zheng, L. Shi, and Z.-T. Wang, "The involvement of p62-Keap1-Nrf2 antioxidative signaling pathway and JNK in the protection of natural flavonoid quercetin against hepatotoxicity," Free Radical Biology and Medicine, vol. 85, pp. 12-23, 2015.

[70] R. Zhou, J. J. Lin, and D. F. Wu, "Sulforaphane induces Nrf2 and protects against CYP2E1-dependent binge alcohol-induced liver steatosis," Biochimica et Biophysica Acta (BBA)—General Subjects, vol. 1840, no. 1, pp. 209-218, 2014.

[71] H.-G. Xin, B.-B. Zhang, Z.-Q. Wu et al., "Treatment with baicalein attenuates methionine-choline deficient diet-induced non-alcoholic steatohepatitis in rats," European Journal of Pharmacology, vol. 738, pp. 310-318, 2014.

[72] B. Li, L. Wang, Q. Lu, and W. Da, "Liver injury attenuation by curcumin in a rat NASH model: an Nrf2 activation-mediated effect?" Irish Journal of Medical Science, vol. 185, no. 1, pp. 93$100,2016$.

[73] L. L. Qu, B. Yu, Z. Li, W. X. Jiang, J. D. Jiang, and W. J. Kong, "Gastrodin ameliorates oxidative stress and proinflammatory response in nonalcoholic fatty liver disease through the AMPK/Nrf2 pathway," Phytotherapy Research, vol. 30, no. 3, pp. 402-411, 2016.

[74] Y. Wang, L. M. Ausman, A. S. Greenberg, R. M. Russell, and X.-D. Wang, "Dietary lycopene and tomato extract supplementations inhibit nonalcoholic steatohepatitis-promoted hepatocarcinogenesis in rats," International Journal of Cancer, vol. 126, no. 8, pp. 1788-1796, 2010.

[75] P. Chen, H. Zeng, Y. Wang et al., "Low dose of oleanolic acid protects against lithocholic acid-induced cholestasis in 
mice: potential involvement of nuclear factor-E2-related factor 2-mediated upregulation of multidrug resistance-associated proteinss," Drug Metabolism and Disposition, vol. 42, no. 5, pp. 844-852, 2014.

[76] P. Chen, J. Li, X. Fan et al., "Oleanolic acid attenuates obstructive cholestasis in bile duct-ligated mice, possibly via activation of NRF2-MRPs and FXR antagonism," European Journal of Pharmacology, vol. 765, Article ID 70177, pp. 131-139, 2015.

[77] C. J. Oh, J.-Y. Kim, A.-K. Min et al., "Sulforaphane attenuates hepatic fibrosis via NF-E2-related factor 2-mediated inhibition of transforming growth factor- $\beta /$ Smad signaling," Free Radical Biology and Medicine, vol. 52, no. 3, pp. 671-682, 2012.

[78] F. Gantner, M. Leist, A. W. Lohse, P. G. Germann, and G. Tiegs, "Concanavalin A-induced T-cell-mediated hepatic injury in mice: the role of tumor necrosis factor," Hepatology, vol. 21, no. 1, pp. 190-198, 1995.

[79] F. Heymann, K. Hamesch, R. Weiskirchen, and F. Tacke, "The concanavalin a model of acute hepatitis in mice," Laboratory Animals, vol. 49, S1, pp. 12-20, 2015.

[80] J. Liu, K. C. Wu, Y.-F. Lu, E. Ekuase, and C. D. Klaassen, "NRF2 protection against liver injury produced by various hepatotoxicants," Oxidative Medicine and Cellular Longevity, vol. 2013, Article ID 305861, 8 pages, 2013.

[81] W. O. Osburn, M. S. Yates, P. D. Dolan et al., "Genetic or pharmacologic amplification of Nrf2 signaling inhibits acute inflammatory liver injury in mice," Toxicological Sciences, vol. 104, no. 1, pp. 218-227, 2008.

[82] A. González-Rodríguez, B. Reibert, T. Amann, R. Constien, C. M. Rondinone, and A. M. Valverde, "In vivo siRNA delivery of Keap1 modulates death and survival signaling pathways and attenuates concanavalin-A-induced acute liver injury in mice," Disease Models and Mechanisms, vol. 7, no. 9, pp. 1093-1100, 2014.

[83] M. J. Tuñón, M. Alvarez, J. M. Culebras, and J. GonzálezGallego, "An overview of animal models for investigating the pathogenesis and therapeutic strategies in acute hepatic failure," World Journal of Gastroenterology, vol. 15, no. 25, pp. 3086-3098, 2009.

[84] L. W. D. Weber, M. Boll, and A. Stampfl, "Hepatotoxicity and mechanism of action of haloalkanes: carbon tetrachloride as a toxicological model," Critical Reviews in Toxicology, vol. 33, no. 2, pp. 105-136, 2003.

[85] L. E. Randle, C. E. P. Goldring, C. A. Benson et al., "Investigation of the effect of a panel of model hepatotoxins on the Nrf2-Keap1 defence response pathway in CD-1 mice," Toxicology, vol. 243, no. 3, pp. 249-260, 2008.

[86] W. Xu, C. Hellerbrand, U. A. Köhler et al., "The Nrf2 transcription factor protects from toxin-induced liver injury and fibrosis," Laboratory Investigation, vol. 88, no. 10, pp. 1068-1078, 2008.

[87] F. Liu, S. Ichihara, W. M. Valentine et al., "Increased susceptibility of Nrf2-null mice to 1-bromopropane-induced hepatotoxicity," Toxicological Sciences, vol. 115, no. 2, pp. 596-606, 2010.

[88] B.-H. Lee, W.-H. Hsu, Y.-W. Hsu, and T.-M. Pan, "Suppression of dimerumic acid on hepatic fibrosis caused from carboxymethyl-lysine (CML) by attenuating oxidative stress depends on Nrf2 activation in hepatic stellate cells (HSCs)," Food and Chemical Toxicology, vol. 62, pp. 413-419, 2013.

[89] C.-L. Liu, J.-M. Wang, C.-Y. Chu, M.-T. Cheng, and T.-H. Tseng, "In vivo protective effect of protocatechuic acid on tert-butyl hydroperoxide-induced rat hepatotoxicity," Food and Chemical Toxicology, vol. 40, no. 5, pp. 635-641, 2002.
[90] D.-S. Lee, K.-S. Kim, W. Ko et al., "The cytoprotective effect of sulfuretin against tert-Butyl Hydroperoxide-induced hepatotoxicity through Nrf2/ARE and JNK/ERK MAPK-mediated Heme Oxygenase-1 expression," International Journal of Molecular Sciences, vol. 15, no. 5, pp. 8863-8877, 2014.

[91] S. Hix, M. B. Kadiiska, R. P. Mason, and O. Augusto, "In vivo metabolism of tert-Butyl hydroperoxide to methyl radicals. EPR spin-trapping and DNA methylation studies," Chemical Research in Toxicology, vol. 13, no. 10, pp. 1056-1064, 2000.

[92] J. M. Oh, Y. S. Jung, B. S. Jeon et al., "Evaluation of hepatotoxicity and oxidative stress in rats treated with tert-butyl hydroperoxide," Food and Chemical Toxicology, vol. 50, no. 5, pp. 1215-1221, 2012.

[93] L. Jarup, "Hazards of heavy metal contamination," British Medical Bulletin, vol. 68, no. 1, pp. 167-182, 2003.

[94] K. C. Wu, J. J. Liu, and C. D. Klaassen, "Nrf2 activation prevents cadmium-induced acute liver injury," Toxicology and Applied Pharmacology, vol. 263, no. 1, pp. 14-20, 2012.

[95] D. Liu, X. Duan, D. Dong et al., "Activation of the Nrf2 pathway by inorganic arsenic in human hepatocytes and the role of transcriptional repressor Bach1," Oxidative Medicine and Cellular Longevity, vol. 2013, Article ID 984546, 10 pages, 2013.

[96] Y. Abiko, Y. Shinkai, D. Sumi, and Y. Kumagai, "Reduction of arsenic-induced cytotoxicity through $\mathrm{Nrf} 2 / \mathrm{HO}-1$ signaling in HepG2 cells," Journal of Toxicological Sciences, vol. 35, no. 3, pp. 419-423, 2010.

[97] X.-F. Wang, M.-L. Xing, Y. Shen, X. Zhu, and L.-H. Xu, "Oral administration of $\mathrm{Cr}(\mathrm{VI})$ induced oxidative stress, DNA damage and apoptotic cell death in mice," Toxicology, vol. 228, no. 1, pp. 16-23, 2006.

[98] A. K. Patlolla, C. Barnes, C. Yedjou, V. R. Velma, and P. B. Tchounwou, "Oxidative stress, DNA damage, and antioxidant enzyme activity induced by hexavalent chromium in SpragueDawley rats," Environmental Toxicology, vol. 24, no. 1, pp. 66-73, 2009.

[99] X. Q. He, G. X. Lin, M. G. Chen, J. X. Zhang, and Q. Ma, "Protection against chromium (VI)-induced oxidative stress and apoptosis by Nrf2. Recruiting Nrf2 into the nucleus and disrupting the nuclear Nrf2/Keap1 association," Toxicological Sciences, vol. 98, no. 1, pp. 298-309, 2007.

[100] C. Torruellas, S. W. French, and V. Medici, "Diagnosis of alcoholic liver disease," World Journal of Gastroenterology, vol. 20, no. 33, pp. 11684-11699, 2014.

[101] D. Wu and A. I. Cederbaum, "Oxidative stress and alcoholic liver disease," Seminars in Liver Disease, vol. 29, no. 2, pp. 141154, 2009.

[102] A. I. Cederbaum, Y. Lu, and D. Wu, "Role of oxidative stress in alcohol-induced liver injury," Archives of Toxicology, vol. 83, no. 6, pp. 519-548, 2009.

[103] P. E. Gong and A. I. Cederbaum, "Nrf2 is increased by CYP2E1 in rodent liver and HepG2 cells and protects against oxidative stress caused by CYP2E1," Hepatology, vol. 43, no. 1, pp. 144-153, 2006.

[104] J. Lamlé, S. Marhenke, J. Borlak et al., "Nuclear factor-eythroid 2-related factor 2 prevents alcohol-induced fulminant liver injury," Gastroenterology, vol. 134, no. 4, pp. 1159-1168, 2008.

[105] K. C. Wu, J. Liu, and C. D. Klaassen, "Role of Nrf2 in preventing ethanol-induced oxidative stress and lipid accumulation," Toxicology and Applied Pharmacology, vol. 262, no. 3, pp. 321-329, 2012. 
[106] H. Azzam and S. Malnick, "Non-alcoholic fatty liver diseasethe heart of the matter," World Journal of Hepatology, vol. 7, no. 10, pp. 1369-1376, 2015.

[107] C. D. Byrne and G. Targher, "NAFLD: a multisystem disease," Journal of Hepatology, vol. 62, no. 1, pp. S47-S64, 2015.

[108] T. Williams, "Metabolic syndrome: nonalcoholic fatty liver disease," FP Essentials, vol. 435, pp. 24-29, 2015.

[109] W. Liu, S. S. Baker, R. D. Baker, and L. Zhu, "Antioxidant mechanisms in nonalcoholic fatty liver disease," Current Drug Targets, vol. 16, no. 12, pp. 1301-1314, 2015.

[110] G. Serviddio, F. Bellanti, and G. Vendemiale, "Free radical biology for medicine: learning from nonalcoholic fatty liver disease," Free Radical Biology and Medicine, vol. 65, pp. 952-968, 2013.

[111] S. Kim, I. Sohn, J.-I. Ahn, K.-H. Lee, Y. S. Lee, and Y. S. Lee, "Hepatic gene expression profiles in a long-term high-fat dietinduced obesity mouse model," Gene, vol. 340, no. 1, pp. 99-109, 2004.

[112] Y. Tanaka, L. M. Aleksunes, R. L. Yeager et al., "NF-E2-related factor 2 inhibits lipid accumulation and oxidative stress in mice fed a high-fat diet," Journal of Pharmacology and Experimental Therapeutics, vol. 325, no. 2, pp. 655-664, 2008.

[113] S. Chowdhry, M. H. Nazmy, P. J. Meakin et al., "Loss of Nrf2 markedly exacerbates nonalcoholic steatohepatitis," Free Radical Biology and Medicine, vol. 48, no. 2, pp. 357-371, 2010.

[114] K. Okada, E. Warabi, H. Sugimoto et al., "Nrf2 inhibits hepatic iron accumulation and counteracts oxidative stress-induced liver injury in nutritional steatohepatitis," Journal of Gastroenterology, vol. 47, no. 8, pp. 924-935, 2012.

[115] H. Sugimoto, K. Okada, J. Shoda et al., "Deletion of nuclear factor-E2-related factor-2 leads to rapid onset and progression of nutritional steatohepatitis in mice," American Journal of Physiology-Gastrointestinal and Liver Physiology, vol. 298, no. 2, pp. G283-G294, 2010.

[116] R. Jadeja, R. V. Devkar, and S. Nammi, "Herbal medicines for the treatment of nonalcoholic steatohepatitis: Current scenario and future prospects," Evidence-Based Complementary and Alternative Medicine, vol. 2014, Article ID 648308, 18 pages, 2014.

[117] J. Xiao, K. F. So, E. C. Liong, and G. L. Tipoe, "Recent advances in the herbal treatment of non-alcoholic fatty liver disease," Journal of Traditional and Complementary Medicine, vol. 3, no. 2, pp. 88-94, 2013.

[118] N. Miloševič, M. Milanovič, L. Abenavoli, and N. Milič, "Phytotherapy and nafld-rom goals and challenges to clinical practice," Reviews on Recent Clinical Trials, vol. 9, no. 3, pp. 195203, 2014.

[119] I. H. Bahcecioglu, N. Kuzu, K. Metin et al., "Lycopene prevents development of steatohepatitis in experimental nonalcoholic steatohepatitis model induced by high-fat diet," Veterinary Medicine International, vol. 2010, Article ID 262179, 8 pages, 2010.

[120] H. Jaeschke, G. J. Gores, A. I. Cederbaum, J. A. Hinson, D. Pessayre, and J. J. Lemasters, "Mechanisms of hepatotoxicity," Toxicological Sciences, vol. 65, no. 2, pp. 166-176, 2002.

[121] J. Weerachayaphorn, A. Mennone, C. J. Soroka et al., "Nuclear factor-E2-related factor 2 is a major determinant of bile acid homeostasis in the liver and intestine," American Journal of Physiology-Gastrointestinal and Liver Physiology, vol. 302, no. 9, pp. G925-G936, 2012.
[122] L. M. Aleksunes, A. L. Slitt, J. M. Maher et al., "Nuclear factorE2-related factor 2 expression in liver is critical for induction of NAD(P)H:quinone oxidoreductase 1 during cholestasis," Cell Stress and Chaperones, vol. 11, no. 4, pp. 356-363, 2006.

[123] K. Okada, J. Shoda, K. Taguchi et al., "Nrf2 counteracts cholestatic liver injury via stimulation of hepatic defense systems," Biochemical and Biophysical Research Communications, vol. 389, no. 3, pp. 431-436, 2009.

[124] K. P. Tan, G. A. Wood, M. Yang, and S. Ito, "Participation of nuclear factor (erythroid 2-related), factor 2 in ameliorating lithocholic acid-induced cholestatic liver injury in mice," British Journal of Pharmacology, vol. 161, no. 5, pp. 1111-1121, 2010.

[125] O. Lukivskaya, L. Zavodnik, M. Knas, and V. Buko, "Antioxidant mechanism of hepatoprotection by ursodeoxycholic acid in experimental alcoholic steatohepatitis," Advances in Medical Sciences, vol. 51, pp. 54-59, 2006.

[126] K. Ishizaki, T. Imada, and M. Tsurufuji, "Hepatoprotective bile acid 'ursodeoxycholic acid (UDCA)': property and difference as bile acids," Hepatology Research, vol. 33, no. 2, pp. 174-177, 2005.

[127] G. Paumgartner and U. Beuers, "Mechanisms of action and therapeutic efficacy of ursodeoxycholic acid in cholestatic liver disease," Clinics in Liver Disease, vol. 8, no. 1, pp. 67-81, 2004.

[128] K. Kawata, Y. Kobayashi, K. Souda et al., "Enhanced hepatic Nrf2 activation after ursodeoxycholic acid treatment in patients with primary biliary cirrhosis," Antioxidants and Redox Signaling, vol. 13, no. 3, pp. 259-268, 2010.

[129] Y.-F. Lu, X.-L. Wan, Y. Xu, and J. Liu, "Repeated oral administration of oleanolic acid produces cholestatic liver injury in mice," Molecules, vol. 18, no. 3, pp. 3060-3071, 2013.

[130] G. L. Plaa and B. G. Priestly, "Intrahepatic cholestasis induced by drugs and chemicals," Pharmacological Reviews, vol. 28, no. 3, pp. 207-273, 1976.

[131] Y. Korenori, S. Tanigawa, T. Kumamoto et al., "Modulation of Nrf2/Keap1 system by Wasabi 6-methylthiohexyl isothiocyanate in ARE-mediated NQO1 expression," Molecular Nutrition and Food Research, vol. 57, no. 5, pp. 854-864, 2013.

[132] E.-J. Joung, M.-H. Li, H. G. Lee et al., "Capsaicin induces heme oxygenase-1 expression in HepG2 cells via activation of PI3K-Nrf2 signaling: $\mathrm{NAD}(\mathrm{P}) \mathrm{H}$ :quinone oxidoreductase as a potential target," Antioxidants and Redox Signaling, vol. 9, no. 12, pp. 2087-2098, 2007.

[133] C.-C. Chen, H.-L. Chen, C.-W. Hsieh, Y.-L. Yang, and B.S. Wung, "Upregulation of NF-E2-related factor-2-dependent glutathione by carnosol provokes a cytoprotective response and enhances cell survival," Acta Pharmacologica Sinica, vol. 32, no. 1, pp. 62-69, 2011.

[134] Y.-J. Jun, M. Lee, T. Shin, N. Yoon, J.-H. Kim, and H.-R. Kim, "Eckol enhances heme oxygenase-1 expression through activation of Nrf2/JNK pathway in HepG2 cells," Molecules, vol. 19, no. 10, pp. 15638-15652, 2014.

[135] A. B. Granado-Serrano, M. A. Martín, G. Haegeman, L. Goya, L. Bravo, and S. Ramos, "Epicatechin induces NF- $\kappa$ B, activator protein-1 (AP-1) and nuclear transcription factor erythroid 2p45-related factor-2 (Nrf2) via phosphatidylinositol3-kinase/protein kinase B (PI3K/AKT) and extracellular regulated kinase (ERK) signalling in HepG2 cells," British Journal of Nutrition, vol. 103, no. 2, pp. 168-179, 2010.

[136] V. Krajka-Kuźniak, J. Paluszczak, L. Celewicz, J. Barciszewski, and W. Baer-Dubowska, "Phloretamide, an apple phenolic compound, activates the Nrf2/ARE pathway in human hepatocytes," Food and Chemical Toxicology, vol. 51, no. 1, pp. 202-209, 2013. 
[137] S. Tanigawa, M. Fujii, and D.-X. Hou, "Action of Nrf2 and Keap1 in ARE-mediated NQO1 expression by quercetin," Free Radical Biology and Medicine, vol. 42, no. 11, pp. 1690-1703, 2007.

[138] V. Krajka-Kuźniak, J. Paluszczak, and W. Baer-Dubowska, "Xanthohumol induces phase II enzymes via Nrf2 in human hepatocytes in vitro," Toxicology in Vitro, vol. 27, no. 1, pp. 149156, 2013.

[139] W. H. Yap, K. S. Khoo, A. S. H. Ho, and Y. M. Lim, "Maslinic acid induces HO-1 and NOQ1 expression via activation of Nrf2 transcription factor," Biomedicine and Preventive Nutrition, vol. 2, no. 1, pp. 51-58, 2012.

[140] S. Chitturi and G. C. Farrell, "Herbal hepatotoxicity: an expanding but poorly defined problem," Journal of Gastroenterology and Hepatology, vol. 15, no. 10, pp. 1093-1099, 2000.

[141] L. I. Mennen, R. Walker, C. Bennetau-Pelissero, and A. Scalbert, "Risks and safety of polyphenol consumption," The American Journal of Clinical Nutrition, vol. 81, no. 1, supplement, pp. 326S329S, 2005.

[142] C. F. Skibola and M. T. Smith, "Potential health impacts of excessive flavonoid intake," Free Radical Biology and Medicine, vol. 29, no. 3-4, pp. 375-383, 2000.

[143] J. Liu, Y.-F. Lu, Y. Zhang, K. C. Wu, F. Fan, and C. D. Klaassen, "Oleanolic acid alters bile acid metabolism and produces cholestatic liver injury in mice," Toxicology and Applied Pharmacology, vol. 272, no. 3, pp. 816-824, 2013.

[144] C. Frenzel and R. Teschke, "Herbal hepatotoxicity: clinical characteristics and listing compilation," International Journal of Molecular Sciences, vol. 17, no. 5, p. 588, 2016.

[145] C. Bunchorntavakul and K. R. Reddy, "Review article: herbal and dietary supplement hepatotoxicity," Alimentary Pharmacology and Therapeutics, vol. 37, no. 1, pp. 3-17, 2013.

[146] M. Muqeet Adnan, M. Khan, S. Hashmi, M. Hamza, S. AbdulMujeeb, and S. Amer, "Black cohosh and liver toxicity: is there a relationship?" Case Reports in Gastrointestinal Medicine, vol. 2014, Article ID 860614, 3 pages, 2014.

[147] T. Y. Lim, A. Considine, A. Quaglia, and D. L. Shawcross, "Subacute liver failure secondary to black cohosh leading to liver transplantation," BMJ Case Reports, vol. 2013, 2013.

[148] R. Teschke and A. Schwarzenboeck, "Suspected hepatotoxicity by Cimicifugae racemosae rhizoma (black cohosh, root): critical analysis and structured causality assessment," Phytomedicine, vol. 16, no. 1, pp. 72-84, 2009.

[149] C. R. Lynch, M. E. Folkers, and W. R. Hutson, "Fulminant hepatic failure associated with the use of black cohosh: a case report," Liver Transplantation, vol. 12, no. 6, pp. 989-992, 2006. 


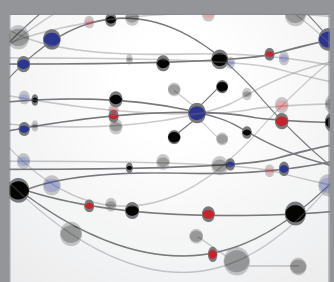

The Scientific World Journal
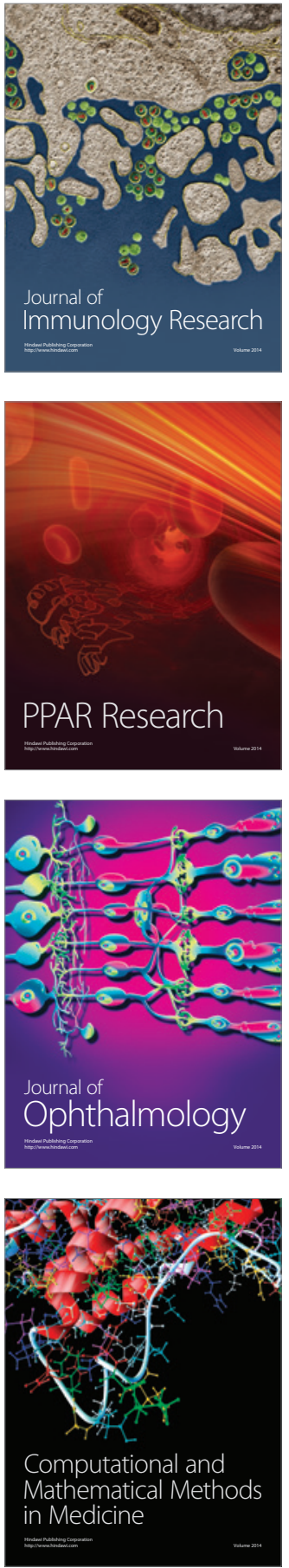

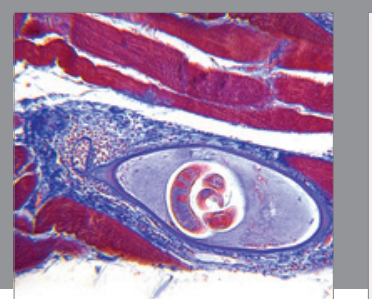

Gastroenterology Research and Practice

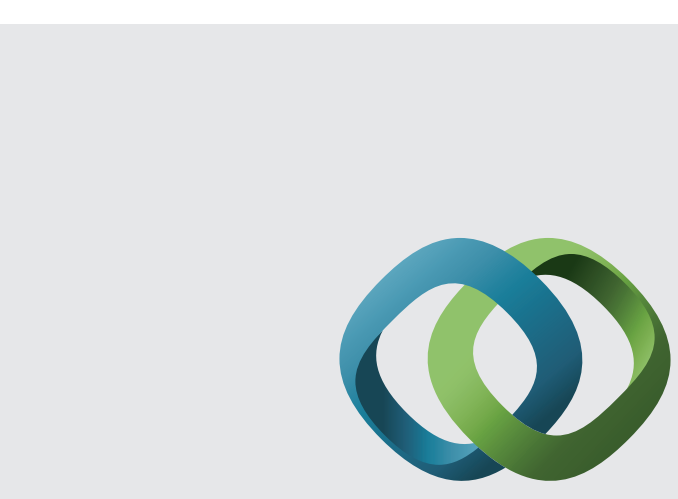

\section{Hindawi}

Submit your manuscripts at

http://www.hindawi.com
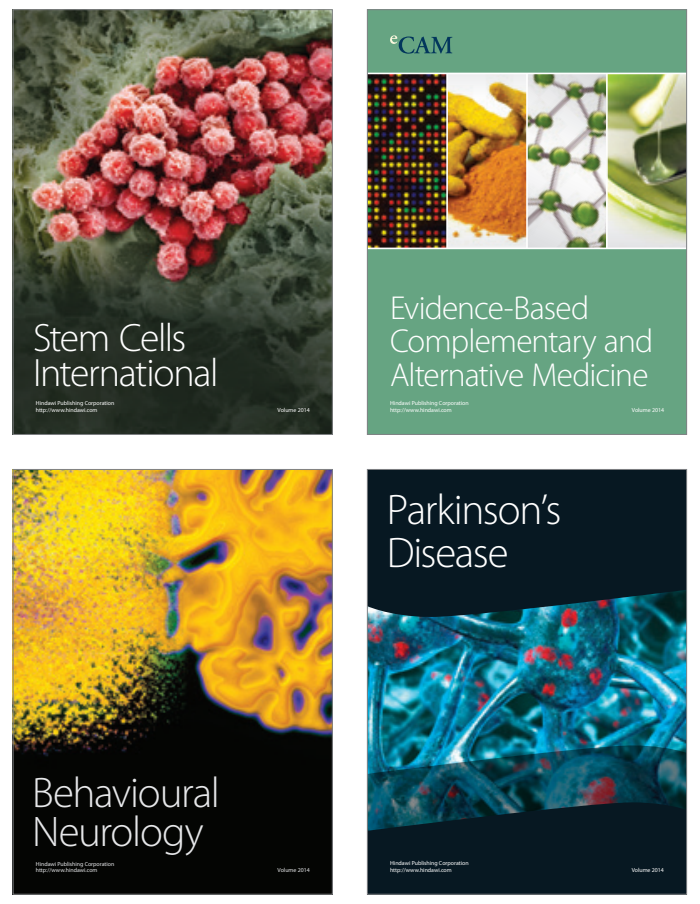
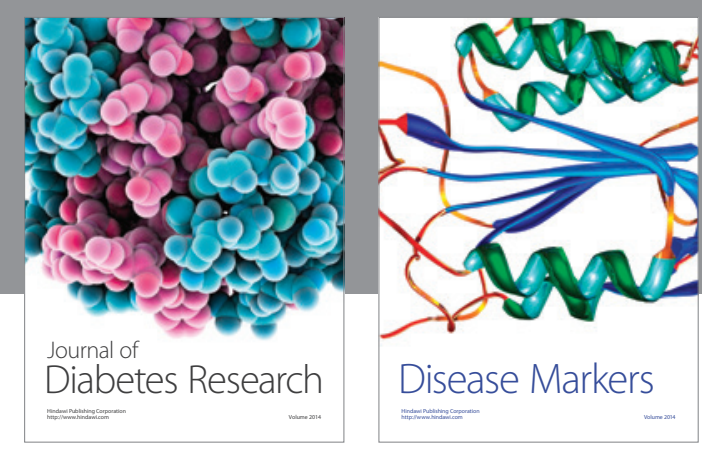

Disease Markers
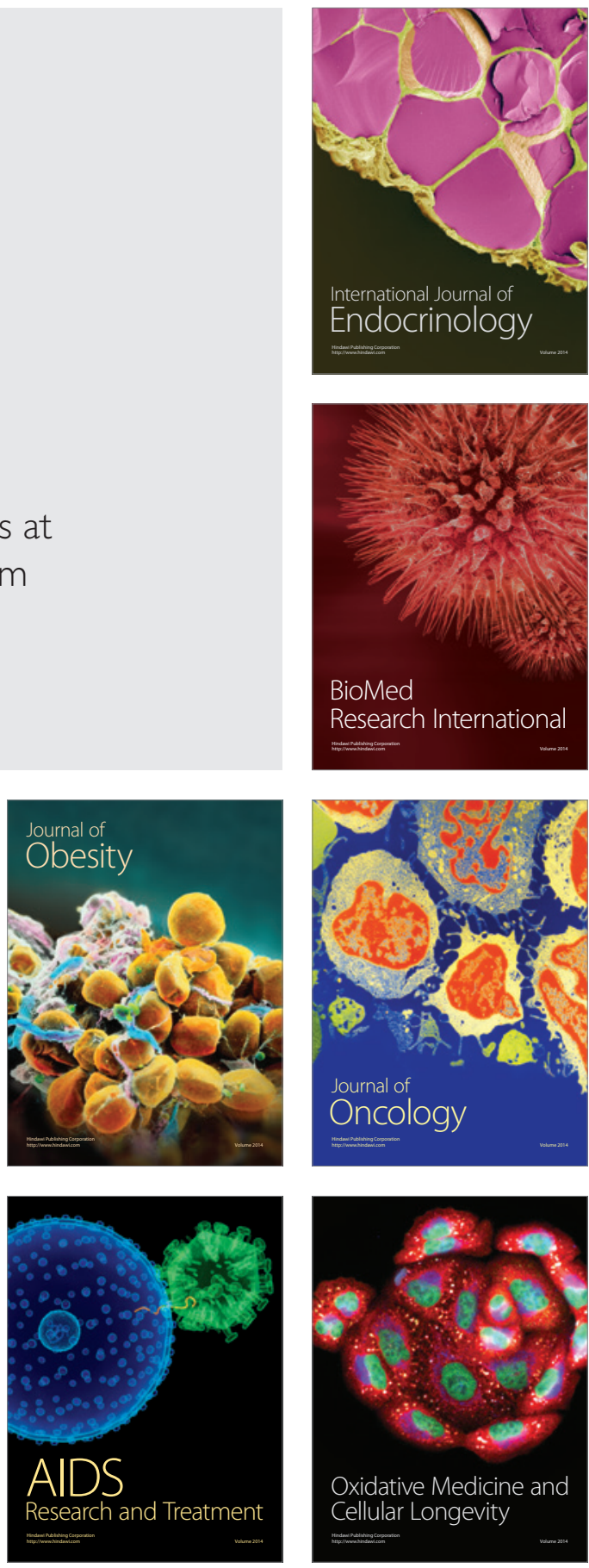